\title{
Synthesis of formyl-thienylpyrroles: versatile building blocks for NLO materials
}

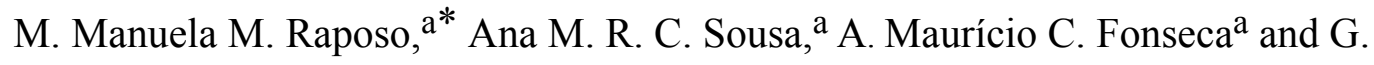 \\ Kirsch $^{b}$ \\ a Centro de Química, Universidade do Minho, Campus de Gualtar \\ 4710-057 Braga, Portugal \\ b Laboratoire d'Ingénierie Moléculaire et Biochimie Pharmacologique, \\ UFR SciFA, Université de Metz, 1, Boulevard Arago, Metz Technopôle, \\ 57078 Metz Cedex 3, France
}

\begin{abstract}
Several formyl-substituted 1-alkyl(aryl)-2-(2'-thienyl)pyrroles 3-7 were synthesized by functionalization of the pyrrole or thiophene ring of thienylpyrroles 2 using different methods: Vilsmeier formylation or metalation followed by reaction with DMF.
\end{abstract}

Keywords: formyl-substituted thienylpyrroles, reactivity studies, Vilsmeier formylation, $m$ , UV-Visible spectroscopy.

\section{Introduction}

Formylation is a key process in organic synthesis, with the resulting aldehyde function being a "crossroads" intermediate. Not surprisingly, a large number of methods have been developed for this reaction. Reagents for electrophilic formylation are mostly of the form $\mathrm{Y}-\mathrm{CH}=\mathrm{X}^{+}$. Thus the reactions attributed to Vilsmeier $\left(\mathrm{ClCH}=\mathrm{NR}_{2}{ }^{+}\right)$, Rieche (e.g. $\left.\mathrm{MeOCHCl}_{2} \rightarrow \mathrm{MeO}=\mathrm{CHCl}^{+}\right)$, Gatterman $\left(\mathrm{Zn}[\mathrm{CN}]_{2} / \mathrm{HCl} \rightarrow \mathrm{HC}=\mathrm{NH}_{2}{ }^{2+}\right)$, GattermanKoch $\left(\mathrm{CO} / \mathrm{HCl} /\right.$ Lewis acid $\left.\rightarrow \mathrm{HC}=\mathrm{O}^{+}\right)$and even Duff $\left(\mathrm{CH}_{2}=\mathrm{NH}_{2}{ }^{+}\right.$- followed by dehydrogenation of initially formed $\mathrm{RCH}_{2} \mathrm{NH}_{2}$ ) all fit this pattern. ${ }^{1}$

Organolithiums are beyond any doubt the most useful metalated heterocycles. Usually they are prepared by direct deprotonation of acidic hydrogens using strong bases or, particulary useful in the case of the less acidic sites in aromatic rings, by halogen exchange between a halogenated heterocycle and an organolithium compound or

*Corresponding author. Phone: +351 253 604381: Fax: +351 253 678983: e-mail: mfox@quimica.uminho.pt 
lithium metal. Another frequent alternative is the so-called ortho-lithiation or "directed ortho-metalation" (DoM) which is the metalation of an aromatic ring adjacent to a heteroatom-containing functional group by providing the lithium base with a point of coordination, thus increasing reactivity close to the coordination site. The lithiated species generated by all these methods are able to react with all kinds of electrophiles. ${ }^{2-}$ 3

Vilsmeier formylation and metalation followed by quenching with DMF constitute the most significant routes for the preparation of formyl-substituted pyrroles and thiophenes. ${ }^{4-5}$

The formyl- derivatives obtained can further react to afford more complex molecules which have made of formyl-thiophenes and formyl-pyrroles some of the most important molecules to be used as building blocks in biological active compounds, supramolecular chemistry and molecular electronics. ${ }^{6-25}$

During the last years we have been concerned with the studies of several organic and organometallic compounds such as oligothiophenes, thienylpyrroles, thienylphthalazines, thienyl and bithienyl- Mo complexes bearing donor and electron acceptor units motivated by their potential applications in optical and electronic devices.25-34 Recently, we have investigated donor-acceptor substituted thienylpyrroles. Due to their solvatochromic, electrochemical and non-linear optical properties, donor-acceptor thienylpyrrole derivatives could be used for the manufacture of semi-conductor materials or materials with strong non-linear optical (NLO) properties. ${ }^{28-31}$ Conjugated 1-(alkyl)aryl-2-(2'-thienyl)pyrroles, as strong $\pi$-electron donor moieties functionalized with the formyl- group on the thiophene or on the pyrrole moiety, could be used as precursors in the preparation of functional $\pi$-conjugated systems with several applications (e.g. NLO). 
As part of our continuing interest in non-linear optical material, in this paper we describe the synthesis of formyl-thienylpyrroles, 3-7 prepared from 1-propyl-2-(2'thienyl)pyrrole 2a and 1-aryl-2-(2'-thienyl)pyrroles $\mathbf{2 b - f .}{ }^{35}$

\section{Results and discussion}

\subsection{Synthesis}

\subsubsection{Synthesis of 1-n-propyl-2-(2'-thienyl)pyrrole 2a}

In order to compare the reactivity of 1-alkyl- and 1-aryl-2-(2'-thienyl)pyrroles through the Vilsmeier reaction and through the metalation followed by quenching with DMF, 1propyl-2-(2'-thienyl)pyrrole 2a was synthesized from $N$-propyl-4-(2'-thienyl)-4oxobutanamide 1a using a combination of the Friedel-Crafts and the Lawesson reactions. ${ }^{35-36}$ Direct amidation of 4-oxo-(2'-thienyl)butanoic acid ${ }^{36}$ with propylamine was carried out through DCC-BtOH mediated reaction. Amide 1a was obtained as a colourless solid in good yield (80\%).

Recently we have demonstrated that the reaction of secondary aryl-(2'-thienyl)-4oxobutanamides with Lawesson's reagent (LR) can yield thienylpyrroles and/or bithiophenes in different ratios depending on the substituent(s) of the precursor arylamines. 35 In the case of the secondary $n$-propyl amide 1a, treatment with an equimolar amount of LR gave only the thienylpyrrole $2 \mathrm{a}$ in $47 \%$ yield.

\subsubsection{Vilsmeier formylation}

Electrophilic substitution reactions of thienylpyrroles were found to be very selective. According to earlier reports, the pyrrole nitrogen atom has a greater ability to delocalize the positive charge of $\sigma$-complexes than the sulfur atom in thiophene; pyrrole is 
therefore considerably more reactive towards electrophilic substitution than thiophene. Even when both $\alpha$-positions of the pyrrole ring are occupied, electrophilic substitution will preferentially occur in the $\beta$-position of the pyrrole ring rather than the $\alpha$-position of the thiophene ring. 4,37-40 The reactivity of these systems has been demonstrated with the use of electrophilic reactions producing derivatives with the electrophile substituted primarily on the pyrrole ring. ${ }^{28-31,39-46}$

To our knowledge, there is only one previous study describing the formylation of thienylpyrroles and this study was performed through the Vilsmeier-Haack reaction on the simple 2-(2'-thienyl)pyrrole and 2-(3'-thienyl)pyrrole. Bouka et al obtained exclusively derivatives formylated on the $\alpha$-position of the pyrrole ring. 40

Therefore, we decided to study the reactivity of different thienylpyrroles bearing $N$ alkyl or $N$-aryl groups on the pyrrole ring through the Vilsmeier-Haack reaction and metalation followed by reaction with DMF.

Accordingly, Vilsmeier formylation of thienylpyrroles 2a-c proceeded selectively in the pyrrole ring to form the corresponding formyl-substituted thienylpyrroles 3-4.

In our studies of Vilsmeier-Haack formylation of 1-propyl-2-(2'-thienyl)pyrrole 2a, the 5-position of the pyrrole ring was found to be much more reactive than the 3-position. The Vilsmeier-Haack formylation of 2a, with $\mathrm{DMF} / \mathrm{POCl}_{3}$ at $60{ }^{\circ} \mathrm{C}$ for $2 \mathrm{~h}$ produced a mixture of 5-formyl- 3a (63\%), and 3-formyl- derivative 4a, in lower yield (5\%) (Table 1, entries 1-2). Under the same experimental conditions 1-aryl-2-(2'-thienyl)pyrroles 2b-c behave quite differently giving a mixture of the 5- and 3-formyl- derivatives in similar yields. Formylation of $\mathbf{2 b}$ gave a mixture of $\mathbf{3 b}(19 \%)$ and $\mathbf{4 b}(22 \%)$, (Table 1 , entries 3-4) and formylation of 2c gave a mixture of 3c (12\%) and 4c (10\%). In comparison to alkylpyrrole 2a the formyl derivatives of 1-aryl-2-(2'-thienyl)pyrroles 2b-c were obtained in lower yields. 


\section{$<$ Scheme 1 $>$}

$<$ Table 1 $>$

In order to interpret the results obtained we consider several factors: (i) an appreciably larger nucleophilicity of the pyrrole ring compared to that of thiophene; (ii) a decrease in the electron density in the pyrrole ring due to the competitive conjugation of the $\mathrm{N}$ aryl group with the unshared electron pair on nitrogen and also due to its negative inductive effect; (iii) possible steric influence due to the $n$-propyl group for attack at the $\alpha$-position of the pyrrole ring. 44

3-Substituted pyrroles are the most difficult to synthesize since most electrophilic aromatic substitution reactions and lithiation reactions of $N$-substituted pyrroles occur at the 2-position and so functionalization at the 3-position of pyrrole is a challenging goal in synthetic research. Bulky substituents on the nitrogen atom promote 3substitution. This observation led to new approaches to the synthesis of 3-substituted pyrroles, as these are normally found only as by products in reactions leading predominantly to 2-substitution. ${ }^{47-49}$ As 3-formyl $N$-arylpyrroles are key synthetic intermediates to highly biologically active compounds the preparation of new derivatives, even in fair yields, still remains an attractive goal. ${ }^{10-11,44,46}$

The structures of formyl-substituted pyrrole derivatives 3-4 were unambiguously confirmed by their analytical and spectral data. In the ${ }^{1} \mathrm{H}$ NMR spectrum of 5-formylsubstituted pyrrole derivatives 3a-c two signals at about 6.40-6.64 and 6.96-7.17 ppm were detected. Both signals appear as doublets with coupling constants of 4.2-4.5 Hz indicating the presence of two adjacent protons $(3-\mathrm{H}$ and $4-\mathrm{H})$ at the corresponding pyrrole moiety. In the ${ }^{1} \mathrm{H}$ NMR spectrum of 3-formyl-substituted pyrrole derivatives 4a-c two signals at about 6.47-6.79 and 6.78-7.19 ppm were detected. Both signals appear as doublets with coupling constants of 3.0-3.3 Hz. These signals were attributed 
to the 5-H and 4-H in the pyrrole moiety. The position of the formyl group in pyrrole derivatives 4a-c was also confirmed through the analysis of 2D NOESY spectra. Thus, the 2D NOESY spectra of compounds 4a-c shows a cross peak of the pyrrole ring 4-H with the formyl group and also a cross peak of the formyl group with the thiophene ring 3 '-H. On the contrary, the 2D NOESY spectrum of compound 4a shows a cross peak of the $\mathrm{NCH}_{2}$ protons of the $n$-propyl group with the $5-\mathrm{H}$ proton of the pyrrole ring but there is no cross peak of the pyrrole ring 5-H with the formyl group. This is taken as evidence for the attachment of the formyl group at ring position 3. In all the ${ }^{1} \mathrm{H}$ NMR spectra of formyl-substituted pyrrole derivatives 3a-c and 4a-c three signals at about 6.90-7.20 (multiplet), 6.72-7.20 (double doublet) and 7.19-7.63 (double doublet) were detected. These signals were attributed respectively, to the 4', 3' and 5'-H protons in the thiophene moiety.

\subsubsection{Metalation followed by reaction with DMF}

As (5'-formyl-2'-thienyl)pyrroles could not be synthesized solely by the VilsmeierHaack reaction, we tried to prepare these compounds by lithiation followed by treatment with DMF.

The electron-rich five member aromatic $N$-substituted pyrrole, furan and thiophene are lithiated at C-2 by direct deprotonation with a lithium-containing base. Several authors have reported the $\alpha$-lithiation of $N$-arylpyrroles using different experimental conditions: $n$-BuLi-TMEDA chelate, $n$-BuLi-tBuOK (LiCKOR) superbase, ter-BuLi-secondary amides, $\mathrm{Na} / \mathrm{dry}$ ether $/ 0{ }^{\mathrm{O}} \mathrm{C} /$ ter-BuLi, ter-BuLi/- $78{ }^{\mathrm{O}} \mathrm{C} / \mathrm{THF}, n$-BuLi/THF/- $78{ }^{\mathrm{O}} \mathrm{C}, n$ BuLi-TMEDA/THF/- $75{ }^{\mathrm{O}} \mathrm{C} .49-54$

Recently, novel methods for site-selective lithiation in $\alpha$ or benzylic positions of 1(methoxyphenyl), 1-(chlorophenyl), 1-(bromophenyl), 1-(trifluoromethylphenyl) and 1(methylphenyl)pyrroles have also been reported. ${ }^{55-59}$ 
To our knowledge, the formylation of thienylpyrroles through lithiation followed by quenching with DMF has not been previously reported, and success would open the way to a new range of formyl-functionalized thienylpyrroles.

The metalation of thienylpyrroles 2 was carried out with $n$-BuLi in dry ether at $0{ }^{\circ} \mathrm{C}$ for $1 \mathrm{~h}$. Subsequently, the organolithium derivatives were converted to the corresponding formyl compounds, by addition of DMF followed by refluxing the mixture for $1 \mathrm{~h}$ (Scheme 2, Table 2). In order to compare the reactivity of pyrroles 2 under the experimental conditions described above the reaction time studied for all derivatives (for the metalation and for the reaction with DMF) was $1 \mathrm{~h}$. As a consequence of the limited reaction time, in some cases, unreacted starting materials remained in the reaction mixtures.

Through this method thienylpyrroles 2a-b and 2e-f were selectively lithiated at the $\alpha$ position of the thiophene ring giving formyl-derivatives $5 \mathbf{a}-\mathbf{b}$ and $\mathbf{5 e - f .}$

The methoxy group is known as a moderately strong ortho directing substituent with electron withdrawal and electron donor properties.3,55,60 At the same time, for compounds 2c-d the 4-methoxy and the 2,4-dimethoxy group(s) have an $\alpha$-directing effect in the aromatic ring. Consequently, the formylation of the aromatic ring was also observed for thienylpyrroles 2c-d (Table 2, entries 4, 6 and 7, compounds 6c-d, 7d) due to the ortho directing effect of the methoxy groups (Scheme 2) giving a mixture of several formylated derivatives with 2-(5'-formyl-2'-thienyl)pyrroles $5 \mathbf{c}-\mathbf{d}$ being the major products.

For compound 2d we studied also the effect of the reaction time for the metalation step and for the reaction with DMF. Metalation of thienylpyrrole $2 \mathbf{d}$ for $2 \mathrm{~h}$ followed by $2 \mathrm{~h}$ of reflux with DMF gave a mixture of 4 compounds: thienylpyrrole 2d (18\%), 1(2', $4^{\prime \prime}$-dimethoxyphenyl)-2-(5'-formyl-2'-thienyl)pyrrole 5d (34\%), 1-(3"'-formyl- 
2",4"'-dimethoxyphenyl)-2-(2'-thienyl)pyrrole 7d (14\%) and 1-(3"'-formyl-2",4"'dimethoxyphenyl)-2-(5'-formyl-2'-thienyl)pyrrole 6d (18\%) (Table 2, entries 5-7). The experiment showed that, instead of improving the yield of compound 5d we obtained the diformylated compound $\mathbf{6} \mathbf{d}$ and a higher yield for the formyl-aryl derivative $\mathbf{7 d}$ as a result of the increase of the reaction time.

Compounds 5e and $\mathbf{5 f}$ were obtained but in lower yields. It should be recorded that we could not isolate any benzylic formyl product from these reactions.

${ }^{1} \mathrm{H}$ NMR spectra of (5'-formyl-2'-thienyl)pyrrole derivatives 5a-f showed two signals at about 6.61-7.12 and 7.49-7.71 ppm. Both signals appear as doublets with coupling constants of 3.9-4.2 Hz indicating the presence of two adjacent protons ( $3{ }^{\prime}-\mathrm{H}$ and $\left.4^{\prime}-\mathrm{H}\right)$ at the corresponding thiophene moiety. In all the ${ }^{1} \mathrm{H}$ NMR spectra of formyl-substituted thiophene derivatives 5a-f three signals at about 6.20-6.42 (multiplet) 6.53-6.77 (double doublet), and 6.82-6.97 (multiplet) were detected. These signals were attributed respectively, to the 4,3 and $5-\mathrm{H}$ protons in the pyrrole moiety.

\section{$<$ Scheme 2>}

$<$ Table 2>

\subsection{UV-visible study of formyl-substituted thienylpyrroles}

The electronic spectra of formyl-thienylpyrrole derivatives were recorded in ethanol (Tables 1-2).

All the formyl-substituted thienylpyrroles 3-7 synthesized exhibit intense absorptions in the UV-visible range. The position of these absorptions is influenced by the structure of the compounds, for example by the substituent on the nitrogen atom of the pyrrole ring 
and by the position of substitution of the formyl group on the thiophene, pyrrole or on the aromatic $\operatorname{ring}(\mathrm{s})$.

Communication between the electron donating and accepting termini can be evaluated by comparing the $\lambda_{\max }$ values. Dramatic differences in energy occur upon formylsubstitution of thienylpyrroles 2. For example, thienylpyrrole $2 \mathbf{d}\left(\lambda_{\max }=286.5 \mathrm{~nm}\right)$ is shifted $98 \mathrm{~nm}$ upon formyl substitution (formyl- derivative $\mathbf{5 d}, \lambda_{\max }=384.5 \mathrm{~nm}$ ) (Table 2, entry 5). This effect has been attributed to the stabilization of LUMO by the electron-withdrawing groups. ${ }^{61}$ The influence of the substituent on the nitrogen atom of the pyrrole ring is demonstrated by comparison of the absorption maxima of compounds $5 \mathbf{a}$ and $\mathbf{5 d}$ as the longest wavelength transition is shifted from $374.0 \mathrm{~nm}$ in 1-(n-propyl)-2-(5'-formyl-2'-thienyl)pyrrole 5a (Table 2, entry 1) to $384.5 \mathrm{~nm}$ for 1 $\left(2^{\prime \prime}, 4^{\prime \prime}\right.$-dimethoxyphenyl)-2-(5'-formyl-2'-thienyl)pyrrole 5d (Table 1, entry 5). The influence of the position of the formyl group on the pyrrole ring on $\lambda_{\max }$ of absorption for formyl derivatives $\mathbf{3}$ and $\mathbf{4}$ is noteworthy. The difference in $\lambda_{\max }$ values $\left(\Delta \lambda_{\max }\right)$ between compounds (3a-b and $\mathbf{4 a - b}$ ) is in the range of 15-28 nm (Table 1, entries 1-4). As expected, the presence of the formyl group on the 5-position of the pyrrole ring (3a3b), relative to the same acceptor group in the 3-position (4a-4b), results in a bathochromic shift in the $\lambda_{\max }$ of absorption for $\mathbf{3 a - 3 b}$ due to more extensive electron delocalization.

\section{Conclusions}

Starting from the readily available thienylpyrroles $\mathbf{2}$, commercial reagents and simple and convenient procedures were used to synthesize new formyl-, thienylpyrroles in fair to good yields, via two methods: Vilsmeier formylation and lithiation followed by reaction with DMF. 
Vilsmeier-Haack formylation of 2 was made at the 3- and 5-positions on the pyrrole ring to give compounds 3-4. These results are in accordance with the greater nucleophilicity of the pyrrole ring versus the thiophene ring as has been shown earlier in the case of the tricyanovinylation reaction and azo coupling reaction of 1-(alkyl)aryl2-(2'-thienyl)pyrroles 2.28-29

The lithiation of thienylpyrroles 2a-b and 2e-f, followed by quenching with DMF, occurred selectively on the $\alpha$ - position of the thiophene ring giving formyl derivatives 5a-b and 5e-f. For compounds 2c-d with methoxy group(s) on the aryl ring was obtained a mixture of formyl-derivatives $\mathbf{5 c - d}, \mathbf{6 c - d}$ and $7 \mathbf{d}$ with the formyl group on the thiophene ring and/or on the aryl ring. The major compounds formed were $(5$ ' formyl-2' - thienyl)pyrroles 5c-d.

The formyl- derivatives 3-7 studied exhibit an absorption band in the UV-visible range influenced by the structure of the compounds: the type of substituent on the nitrogen atom of the pyrrole ring and also by the position of the formyl group on the thiophene or on the pyrrole ring.

The conjugated formyl derivatives of 1-alkyl(aryl)-2-(2'-thienyl)pyrroles will be used in the future, as precursors in the preparation of compounds with a stronger electronwithdrawing group for potential applications in NLO. 22,25

\section{Experimental}

\subsection{General}

${ }^{1} \mathrm{H}$ NMR spectra were obtained on a Varian Unity Plus Spectrometer at $300 \mathrm{MHz}$ and ${ }^{13} \mathrm{C}$ NMR spectra were determinated on a Varian Unity Plus Spectrometer at $75.4 \mathrm{MHz}$ using the solvent peak as internal reference. The solvents are indicated in parenthesis before the chemical shift values ( $\delta$ relative to TMS). Mps were determined on a Gallenkamp apparatus and are uncorrected. Infrared spectra were recorded on a Perkin 
Elmer 1600 FTIR spectrophotometer. UV-visible absorption spectra were obtained using a Shimadzu UV/2501PC spectrophotometer. EI mass spectra EI (70 eV) and HRMS were run on a Unicam GC-MS 120. Elemental analysis was carried out on a Leco CHNS-932. Column chromatography was performed on Merck silica gel 60 (Art 9385). Light petroleum refers to solvent boiling in the range $40-60{ }^{\circ} \mathrm{C}$.

The synthesis of 1-aryl-2-(2'-thienyl)pyrroles $\mathbf{2} \mathbf{b}$-g has been described elsewhere. ${ }^{35}$

\subsection{Synthesis of 1-propyl-2-(2'-thienyl)pyrrole 2a}

(i) Synthesis of N-propyl-4-(2'-thienyl)-4-oxobutanamide 1a. Amide 1a was obtained using the experimental method described in refs. 35-36, by reacting 4-oxo-(2thienyl)butanoic acid $(5.4 \mathrm{mmol})$ in $\mathrm{CH}_{2} \mathrm{Cl}_{2}$ with 1,3-dicyclohexylcarbodiimide (7.1 $\mathrm{mmol})$ and $\mathrm{BtOH}(7.1 \mathrm{mmol})$ and adding propylamine $(5.4 \mathrm{mmol})$ at $\mathrm{rt}$.

N-Propyl-4-(2'-thienyl)-4-oxobutanamide 1a. Colourless solid (80\%). Mp 96.2-97.6 ${ }^{\circ} \mathrm{C}(\mathrm{EtOH})$. IR (liquid film) v $3311(\mathrm{NH}), 3029,1661(\mathrm{C}=\mathrm{O}), 1645(\mathrm{C}=\mathrm{O}), 1552,1523$, $1420,1397,1248,1179,1063,983,954,910,851,717 \mathrm{~cm}^{-1} .{ }^{1} . \quad \mathrm{R}\left(\mathrm{CDCl}_{3}\right) \delta 0.92(\mathrm{t}$, $\left.3 \mathrm{H}, J=7.2 \mathrm{~Hz}, \mathrm{CH}_{3}\right), 1.52\left(\mathrm{~m}, 2 \mathrm{H}, \mathrm{CH}_{2} \mathrm{CH}_{3}\right), 2.61$ (t, $\left.2 \mathrm{H}, J=7.8 \mathrm{~Hz}, \mathrm{CONHCH}_{2}\right), 5.78$ (br s, 1H, NH), 7.13-7.15 (m, 1H, 4'-H) 7.65 (dd, 1H, J=5.1 and $\left.1.2 \mathrm{~Hz}, 5^{\prime}-\mathrm{H}\right), 7.78$ (dd, $1 \mathrm{H}, J=3.7$ and $\left.1.2 \mathrm{~Hz}, 3^{\prime}-\mathrm{H}\right) .{ }^{13} \mathrm{C} \mathrm{NMR}\left(\mathrm{CDCl}_{3}\right) \delta 11.30,22.76,30.26,34.62$, 41.27, 128.16, 132.23, 133.73, 143.59, 171.71, 192.09. Anal. Calcd for $\mathrm{C}_{11} \mathrm{H}_{15} \mathrm{NO}_{2} \mathrm{~S}$ : C, 58.63; H, 6.72; N, 6.22; S, 14.23. Found: C, 58.63; H, 6.71; N, 6.23; S, 13.98.

(ii) Reaction of amide 1a with Lawesson's Reagent. Thienylpyrrole 2a was obtained using the experimental method described in refs. 35-36, by heating the amide 1a $(2.3$ $\mathrm{mmol})$ in toluene $(12 \mathrm{ml})$ with the Lawesson reagent $(2.3 \mathrm{mmol})$ at reflux during 30 $\min$. .

1-Propyl-2-(2'-thienyl)pyrrole 2a. Orange oil (47\%). UV (EtOH): $\lambda_{\max } \mathrm{nm}\left(\varepsilon / \mathrm{M}^{-1}\right.$ $\mathrm{cm}^{-1}$ ) 291.0 (1803), 225.5 (2054). IR (liquid film) v 3102, 2964, 2932, 2874, 1508, $1470,1430,1383,1345,1299,1234,1201,1108,1070,941,896,844,783,711,613$ 
$\mathrm{cm}^{-1} \cdot{ }^{1} . \quad \mathrm{R}\left(\mathrm{CDCl}_{3}\right) \delta 0.92\left(\mathrm{t}, 3 \mathrm{H}, J=7.2 \mathrm{~Hz},\left(\mathrm{CH}_{2}\right)_{2} \mathrm{CH}_{3}\right), 1.65-1.68(\mathrm{~m}, 2 \mathrm{H}$, $\left.\mathrm{CH}_{2} \mathrm{CH}_{2} \mathrm{CH}_{3}\right), 3.97$ (t, $\left.2 \mathrm{H}, J=7.2 \mathrm{~Hz}, \mathrm{NCH}_{2}\right), 6.17-6.22(\mathrm{~m}, 1 \mathrm{H}, 4-\mathrm{H}), 6.31(\mathrm{dd}, 1 \mathrm{H}$, $J=3.6$ and $1.8 \mathrm{~Hz}, 3-\mathrm{H}), 6.76-6.88(\mathrm{~m}, 1 \mathrm{H}, 5-\mathrm{H}) 7.01\left(\mathrm{dd}, 1 \mathrm{H}, J=3.6\right.$ and $\left.1.2 \mathrm{~Hz}, 3^{\prime}-\mathrm{H}\right)$, 7.06-7.09 (m, 1H, $\left.4^{\prime}-\mathrm{H}\right), 7.29\left(\mathrm{dd}, 1 \mathrm{H}, J=5.1\right.$ and $\left.1.2 \mathrm{~Hz}, 5{ }^{\prime}-\mathrm{H}\right) .{ }^{13} \mathrm{C} \mathrm{NMR}\left(\mathrm{CDCl}_{3}\right) \delta$ 11.17, 24.74, 48.99, 107.71, 110.16, 122.68, 124.71, 125.29, 126.28, 127.16, 134.97. MS (EI) m/z (\%): $191\left(\mathrm{M}^{+}, 100\right), 162$ (50), 149 (34), 130 (7), 121 (13), 111 (40), 104 (15). HRMS: $\mathrm{m} / \mathrm{z}$ (EI) for: $\mathrm{C}_{11} \mathrm{H}_{13} \mathrm{NS}$; calcd 191.0768; found: 191.0763 .

\subsection{General procedure for the synthesis of formyl derivatives 3-4 of 1-(alkyl)aryl- 2-(2'-thienyl)pyrroles 2a-c through Vilsmeier formylation}

$\mathrm{POCl}_{3}(0.46 \mathrm{mmol})$ was added to $\mathrm{DMF}(0.46 \mathrm{mmol})$ at $0{ }^{\circ} \mathrm{C}$ and the mixture was stirred for $15 \mathrm{~min}$. at $0{ }^{\circ} \mathrm{C}$. After this time pyrroles $2(0.39 \mathrm{mmol})$ dissolved in DMF $(1 \mathrm{ml})$ were added dropwise with stirring. The reaction mixture was then heated $2 \mathrm{~h}$ at $60{ }^{\circ} \mathrm{C}$. The solution was then poured slowly into $5 \mathrm{ml}$ saturated sodium acetate aqueous solution and stirred $30 \mathrm{~min}$. The organic layer was diluted with ether, washed with saturated $\mathrm{NaHCO}_{3}$ aqueous solution, and dried with anhydrous $\mathrm{MgSO}_{4}$. Evaporation of the organic extract under reduced pressure gave a mixture of 5-formyl- 3 and 3formylpyrroles 4 which were purified by "flash" chromatography on silica with increasing amounts of ether in light petroleum as eluent.

Vilsmeier formylation of 2a gave a mixture of 5-formyl-1-propyl-2-(2'-thienyl)pyrrole 3a and 3-formyl-1-propyl-2-(2'-thienyl)pyrrole 4a. The first component eluted was 5formyl-1-propyl-2-(2'-thienyl)pyrrole 3a as a green oil (63\%). UV (EtOH): $\lambda_{\max } \mathrm{nm}$ $\left(\varepsilon / \mathrm{M}^{-1} \mathrm{~cm}^{-1}\right), 321.5$ (24650). IR (liquid film): $v$ 2964, $1658(\mathrm{C}=\mathrm{O}), 1509,1473,1428$, 1396, 1314, 1294, 1251, 1225, 1198, 1154, 1042, 847, 776, $702 \mathrm{~cm}^{-1} .{ }^{1} \mathrm{H}$ NMR $\left(\mathrm{CDCl}_{3}\right) \delta 0.90\left(\mathrm{t}, 3 \mathrm{H}, J=7.5 \mathrm{~Hz},\left(\mathrm{CH}_{2}\right)_{2} \mathrm{CH}_{3}\right), 1.70-1.82\left(\mathrm{~m}, 2 \mathrm{H}, \mathrm{CH}_{2} \mathrm{CH}_{2} \mathrm{CH}_{3}\right), 4.41(\mathrm{t}$, $\left.2 \mathrm{H}, J=7.8 \mathrm{~Hz}, \mathrm{NCH}_{2}\right), 6.40$ (d, 1H, J=4.2 Hz, 3-H), 6.96 (d, 1H, J=4.2 Hz, 4-H), 7.127.16 (m, 1H, 4'-H), 7.18 (dd, $1 \mathrm{H}, J=3.6$ and $\left.1.2 \mathrm{~Hz}, 3^{\prime}-\mathrm{H}\right), 7.44$ (dd, $1 \mathrm{H}, J=5.1$ and 1.2 $\mathrm{Hz}, 5$ '-H), 9.54 (s, 1H, CHO). ${ }^{13} \mathrm{C} \mathrm{NMR}\left(\mathrm{CDCl}_{3}\right) \delta 10.80,24.68,47.50,111.89,124.73$ (two overlapped signals), 127.00, 127.42, 127.59, 132.17, 132.51, 136.36. MS (EI) $\mathrm{m} / \mathrm{z}$ (\%): $219\left(\mathrm{M}^{+}, 100\right), 218$ (21), 204 (16), 202 (74), 190 (28), 177 (80), 176 (77), 162 (18), 148 (16), 121 (30), 104 (7). HRMS: (EI) m/z (\%) for $\mathrm{C}_{12} \mathrm{H}_{13} \mathrm{NOS}$; calcd 
219.0718; found 219.0720. The second component eluted was 3-formyl-1-propyl-2-(2'thienyl)pyrrole 4a as a brown oil (5\%). UV (EtOH): $\lambda \max n m\left(\varepsilon / \mathrm{M}^{-1} \mathrm{~cm}^{-1}\right), 293.5$ (5440), 248.0 (10388), 211.0 (8678). IR (liquid film): $v 1662(\mathrm{C}=\mathrm{O}), 1485,1446,1382$, 1257, 849, 765, $706 \mathrm{~cm}^{-1} .{ }^{1} \mathrm{H}$ NMR $\left(\mathrm{CDCl}_{3}\right) \delta 0.87\left(\mathrm{t}, 3 \mathrm{H}, \mathrm{J}=7.5 \mathrm{~Hz},\left(\mathrm{CH}_{2}\right)_{2} \mathrm{CH}_{3}\right)$, 1.65-1.82 (m, 2H, $\mathrm{CH}_{2} \mathrm{CH}_{2} \mathrm{CH}_{3}$ ), 3.87 (t, 2H, J=7.2 Hz, $\mathrm{NCH}_{2}$ ), 6.47 (d, 1H, J=3.3 Hz, 5-H), 6.78 (d, 1H, J=3.3 Hz, 4-H), 7.13-7.20 (m, 2H, 3'and 4'-H), 7.54 (dd, 1H, J=5.1 and $\left.1.2 \mathrm{~Hz}, 5^{\prime}-\mathrm{H}\right), 9.54$ (s, 1H, CHO). MS (EI) m/z (\%): $219\left(\mathrm{M}^{+}, 100\right), 218$ (19), 190 (12), 174 (11), 162 (24), 149 (10), 130 (4), 121 (6), 104 (7), 89 (5). HRMS: (EI) m/z (\%) for $\mathrm{C}_{12} \mathrm{H}_{13} \mathrm{NOS}$; calcd 219.0718; found 219.0708.

Vilsmeier formylation of $\mathbf{2 b}$ gave a mixture of 5-formyl-1-phenyl-2-(2'-thienyl)pyrrole $\mathbf{3 b}$ and 3-formyl-1-phenyl-2-(2'-thienyl)pyrrole $\mathbf{4 b}$. The first component eluted was 5formyl-1-phenyl-2-(2'-thienyl)pyrrole $3 \mathbf{b}$ as a pale yellow solid (19\%). Mp: 72.6-73.9 ${ }^{\circ} \mathrm{C}$. UV (EtOH): $\lambda_{\max } \mathrm{nm}\left(\varepsilon / \mathrm{M}^{-1} \mathrm{~cm}^{-1}\right), 340.5$ (20100), 253.0 (8630). IR (liquid film): v 1660 (CHO), 1596, 1511, 1497, 1469, 1433, 1406, 1361, 1318, 1046, 847, 775, 695, $547 \mathrm{~cm}^{-1} .{ }^{1} \mathrm{H}$ NMR $\left(\mathrm{CDCl}_{3}\right) \delta 6.64(\mathrm{~d}, 1 \mathrm{H}, J=4.2 \mathrm{~Hz}, 3-\mathrm{H}), 6.72(\mathrm{dd}, 1 \mathrm{H}, J=3.9$ and 1.2 $\left.\mathrm{Hz}, 3^{\prime}-\mathrm{H}\right), 6.86-6.90$ (m, 1H, 4'-H), 7.17 (d, 1H, J=4.2 Hz, 4-H), 7.19 (dd, 1H, J=5.1 and $\left.1.2 \mathrm{~Hz}, 5^{\prime}-\mathrm{H}\right), 7.33-7.39(\mathrm{~m}, 2 \mathrm{H}, 2 \mathrm{xAr}-\mathrm{H}), 7.49-7.56(\mathrm{~m}, 3 \mathrm{H}, 3 \mathrm{xAr}-\mathrm{H}) 9.39(\mathrm{~s}, 1 \mathrm{H}$, CHO). ${ }^{13} \mathrm{C} \mathrm{NMR}\left(\mathrm{CDCl}_{3}\right) \delta 109.72,110.96,120.51,126.43,126.62,127.21,128.87$, 129.34, 129.46, 132.66, 136.45, 137.15, 178.76. MS (EI) m/z (\%): $253\left(\mathrm{M}^{+}, 100\right), 225$ (12), 175 (11), 147 (10), 121 (20), 77 (12). HRMS: (EI) m/z (\%) for $\mathrm{C}_{15} \mathrm{H}_{11} \mathrm{NOS}$; calcd 253.0561; found 253.0558. The second component eluted was 3-formyl-1-phenyl-2-(2'thienyl)pyrrole $\mathbf{4 b}$ as pale yellow solid (22\%). Mp: 106.9-107.8 ${ }^{\circ} \mathrm{C}$. UV (EtOH): $\lambda_{\max }$ $\mathrm{nm}\left(\varepsilon / \mathrm{M}^{-1} \mathrm{~cm}^{-1}\right) 325.0$ (7440) IR (liquid film): v 1661 (CHO), 1596, 1496, 1473, 1449, 1413, 1241, 848, 762, $695 \mathrm{~cm}^{-1}$. ${ }^{1} \mathrm{H}$ NMR (Acetone-d 6 ) $\delta 6.79$ (d, 1H, J=3.0 Hz, 5-H), 7.10-7.13 (m, 1H, 4'-H), 7.15-7.19 (m, 2H, 4-H and 3'-H), 7.30-7.36 (m, 2H, 2xAr-H), 7.43-7.49 (m, 3H, 3xAr-H), 7.63 (dd, $1 \mathrm{H}, J=5.1$ and $1.2 \mathrm{~Hz}, 5$ '-H), 9.82 (s, 1H, CHO). ${ }^{13} \mathrm{C} \mathrm{NMR}\left(\mathrm{CDCl}_{3}\right) \delta 108.14,110.95,125.44,126.27,127.09,128.20,128.48,129.18$, 130.61, 132.66, 134.92, 138.60, 186.76. MS (EI) m/z (\%): $253\left(\mathrm{M}^{+}, 100\right), 224$ (19), 209 (14), 180 (5), 121 (11), 77 (22). HRMS: (EI) $\mathrm{m} / \mathrm{z}(\%)$ for $\mathrm{C}_{15} \mathrm{H}_{11} \mathrm{NOS}$; calcd 253.0561; found 253.0576 . 
Vilsmeyer formylation of 2c gave a mixture of 5-formyl-1-(4"'-methoxyphenyl)-2-(2'thienyl)pyrrole 3c and 3-formyl-1-(4'-methoxyphenyl)-2-(2'-thienyl)pyrrole 4c. The first component eluted was 5-formyl-1-phenyl-2-(2'-thienylpyrrole 3c as a yellow solid (12\%). Mp: 110.5-111.9 ${ }^{\circ} \mathrm{C}$. UV (EtOH): $\lambda_{\max } \mathrm{nm}\left(\varepsilon / \mathrm{M}^{-1} \mathrm{~cm}^{-1}\right), 343.0$ (21559), 257.5 (8165), 226.5 (14668). IR (liquid film): $v 1655$ (CHO), 1512, 1495, 1395, 1337, 1319, $1248,1230,1193,1162,1103,1052,832,805,779,765,709 \mathrm{~cm}^{-1} .{ }^{1} \mathrm{H} \mathrm{NMR}\left(\mathrm{CDCl}_{3}\right) \delta$ 3.89 (s, 3H, $\left.\mathrm{OCH}_{3}\right), 6.63$ (d, 1H, J=4.5 Hz, 3-H), 6.80 (dd, 1H, J=3.8 and 1.2 Hz, 3'-H), 6.88-6.92 (m, 1H, 4'-H), 7.00 (d, 2H, J=9.0 Hz, 2xAr-H), 7.15 (d, 1H, J=4.5 Hz, 4-H), $7.19\left(\mathrm{dd}, 1 \mathrm{H}, J=5.1\right.$ and $\left.1.2 \mathrm{~Hz}, 5^{\prime}-\mathrm{H}\right), 7.26$ (d, 2H, J=9.0 Hz, 2xAr-H), 9.38 (s, 1H, $\mathrm{CHO}) .{ }^{13} \mathrm{C} \mathrm{NMR}\left(\mathrm{CDCl}_{3}\right) \delta 55.49,110.58,114.45,120.38,126.41,126.51,127.16$, 129.54, 129.88, 132.71, 134.76, 136.69, 160.17, 178.88. MS (EI) m/z (\%): $283\left(\mathrm{M}^{+}\right.$, 100), 254 (19), 240 (30), 175 (48), 147 (18), 121 (16), 108 (6). HRMS: (EI) m/z (\%) for $\mathrm{C}_{16} \mathrm{H}_{13} \mathrm{NO}_{2} \mathrm{~S}$; calcd 283.0667; found 283.0664. Anal. Calcd for $\mathrm{C}_{16} \mathrm{H}_{13} \mathrm{NO}_{2} \mathrm{~S}$ : C, 67.83; H, 4.69; N, 4.94; S, 11.33. Found: C, 67.58; H, 4.96; N, 4.91; S, 10.82. The second component eluted was 3-formyl-1-(4"'-methoxyphenyl)-2-(2'-thienyl)pyrrole 4c as pale yellow solid (10\%). Mp: 99.7-101.0 ${ }^{\circ} \mathrm{C}$. IR (liquid film): $v 1661$ (CHO), 1512, 1449, 1300, 1242, 1028, 835, $763 \mathrm{~cm}^{-1} .{ }^{1} \mathrm{H}$ NMR (Acetone-d $\left.{ }_{6}\right) \delta 3.86\left(\mathrm{~s}, 3 \mathrm{H}, \mathrm{OCH}_{3}\right.$ ), $6.76(\mathrm{~d}, 1 \mathrm{H}, J=3.0 \mathrm{~Hz}, 5-\mathrm{H}), 7.00(\mathrm{~d}, 2 \mathrm{H}, J=9.0 \mathrm{~Hz}, 2 \times \mathrm{Ar}-H), 7.08$ (dd, $1 \mathrm{H}, J=3.0$ and $1.0 \mathrm{~Hz}, 4-\mathrm{H}), 7.09-7.13$ (m, 1H, 4'-H), 7.16 (dd, 1H, J=3.4 and 1.2 Hz, 3'-H), 7.25 (d, $2 \mathrm{H}, J=9.0 \mathrm{~Hz}, 2 \mathrm{xAr}-\mathrm{H}), 7.61\left(\mathrm{dd}, 1 \mathrm{H}, J=5.1\right.$ and $1.2 \mathrm{~Hz}, 5$ '-H), 9.81 (s, 1H, CHO). ${ }^{13} \mathrm{C}$ NMR $\left(\mathrm{CDCl}_{3}\right) \delta 55.46,107.85,114.24,125.43,125.68,127.03,127.55,128.40$, 129.54, 129.90, 130.51, 131.47, 135.23, 186.71. MS (EI) m/z (\%): $283\left(\mathrm{M}^{+}, 100\right), 254$ (13), 240 (26), 210 (5), 175 (11), 121 (8). HRMS: (EI) m/z \%) for $\mathrm{C}_{16} \mathrm{H}_{13} \mathrm{NO}_{2} \mathrm{~S}$; calcd 283.0667; found 283.0666. Anal. Calcd for $\mathrm{C}_{16} \mathrm{H}_{13} \mathrm{NO}_{2} \mathrm{~S}: \mathrm{C}, 67.83 ; \mathrm{H}, 4.59 ; \mathrm{N}, 4.94 ; \mathrm{S}$, 11.33. Found: C, 67.64; H, 4.98; N, 4.91; S, 11.03.

\subsection{General procedure for the synthesis of formyl- derivatives of 1-(alkyl)aryl-2- (2'-thienyl)pyrroles 2a-f, via metalation with $n$-BuLi followed by reaction with DMF}

A $2.5 \mathrm{M}$ solution of $n$-BuLi in hexanes $(0.44 \mathrm{ml}, 1.1 \mathrm{mmol})$ was dropped under Ar at $0^{\circ}$ $\mathrm{C}$ to a stirred solution of thienylpyrroles $2(1.0 \mathrm{mmol})$ in anhydrous ether. The reaction mixture was then stirred $1 \mathrm{~h}$ at $0^{\circ} \mathrm{C}$ and was allowed to stand $15 \mathrm{~min}$. at room 
temperature. DMF $(0.05 \mathrm{ml}, 1.0 \mathrm{mmol})$ dissolved in anhydrous ether $(2 \mathrm{ml})$ was added dropwise at r.t. The mixture was heated at reflux for $1 \mathrm{~h}$. The mixture was poured into water $(20 \mathrm{ml})$ and extracted with $(3 \times 50 \mathrm{ml})$ of ethyl acetate. The combined organic extracts were washed with $\mathrm{H}_{2} \mathrm{O}(100 \mathrm{ml})$, dried with $\mathrm{MgSO}_{4}$ and the solvent was evaporated under reduced pressure to give the crude 1-(alkyl)aryl-2-(5'-formyl-2'thienyl)pyrroles 5 or a mixture of formyl- derivatives 5, 6 and 7, which were purified by "flash" chromatography on silica with increasing amounts of ether in light petroleum as eluent.

Metalation of thienylpyrrole 2a followed by a reaction with DMF gave a mixture of 2a and 1-propyl-2-(5'-formyl-2'-thienyl)pyrrole 5a The first compound eluted was thienylpyrrole 2a (19\%). The second compound eluted was 1-propyl-2-(5'-formyl-2'thienyl)pyrrole $5 \mathrm{a}$ as an orange oil $(68 \%)$. UV (EtOH): $\lambda_{\max } \mathrm{nm}\left(\varepsilon / \mathrm{M}^{-1} \mathrm{~cm}^{-1}\right) 374.0$ (9474). IR (liquid film): v 1659 (C=O), 1554, 1513, 1475, 1436, 1381, 1283, 1229, 1061, 941, 808, 724, 668, 611, $506 \mathrm{~cm}^{-1} .{ }^{1} \mathrm{H}$ NMR $\left(\mathrm{CDCl}_{3}\right) \delta 0.93(\mathrm{t}, 3 \mathrm{H}, J=7.5 \mathrm{~Hz}$, $\left.\left(\mathrm{CH}_{2}\right)_{2} \mathrm{CH}_{3}\right), 1.77-1.90\left(\mathrm{~m}, 2 \mathrm{H}, \mathrm{CH}_{2} \mathrm{CH}_{2} \mathrm{CH}_{3}\right), 4.08$ (t, $\left.2 \mathrm{H}, \mathrm{J}=7.5 \mathrm{~Hz}, \mathrm{NCH}_{2}\right), 6.20-6.22$ $(\mathrm{m}, 1 \mathrm{H}, 4-\mathrm{H}), 6.53(\mathrm{dd}, 1 \mathrm{H}, J=3.9$ and $1.8 \mathrm{~Hz}, 3-\mathrm{H}), 6.82-6.86(\mathrm{~m}, 1 \mathrm{H}, 5-\mathrm{H}), 7.12(\mathrm{~d}$, 1H, J=3.9 Hz, 3'-H), 7.71 (d, 1H, J=3.9 Hz, 4'-H), 9.87 (s, 1H, CHO). ${ }^{13} \mathrm{C}$ NMR $\left(\mathrm{CDCl}_{3}\right) \delta 11.06,24.61,49.64,108.70,112.38,112.44,125.56,125.70,137.22,140.94$, 145.32, 182.54. MS (EI) m/z (\%): 219 (M+, 100), 218 (9), 191 (19), 177 (26), 176 (23), 162 (17), 148 (7), 104 (7), 78 (2). HRMS: (EI) m/z (\%) for $\mathrm{C}_{12} \mathrm{H}_{13} \mathrm{NOS}$; calcd 219.0718; found 219.0718.

Metalation of thienylpyrrole $\mathbf{2 b}$ followed by a reaction with DMF gave a mixture of $\mathbf{2 b}$ and 1-phenyl-2-(5'-formyl-2'-thienyl)pyrrole 5b. The first compound eluted was thienylpyrrole $\mathbf{2 b}$ (9\%). The second compound eluted was 1-phenyl-2-(5'-formyl-2'thienyl)pyrrole $\mathbf{5 b}$ as a dark orange oil (78\%). UV (EtOH): $\lambda_{\max } \mathrm{nm}\left(\varepsilon / \mathrm{M}^{-1} \mathrm{~cm}^{-1}\right)$ 374.0 (19180), 260.0 (7000). IR (liquid film): v 1659 (CHO), 1597, 1498, 1461, 1438, 1230, 1062, 916, 802, 724, 696, $667 \mathrm{~cm}^{-1} .{ }^{1} \mathrm{H} \mathrm{NMR}\left(\mathrm{CDCl}_{3}\right) \delta 6.36-6.38(\mathrm{~m}, 1 \mathrm{H}, 4-\mathrm{H})$, $6.61\left(\mathrm{~d}, 1 \mathrm{H}, J=4.2 \mathrm{~Hz}, 3^{\prime}-\mathrm{H}\right), 6.71(\mathrm{dd}, 1 \mathrm{H}, J=3.6$ and $1.5 \mathrm{~Hz}, 3-\mathrm{H}), 6.94-6.97(\mathrm{~m}, 1 \mathrm{H}$, 5-H), 7.28-7.33 (m, 2H, 2xAr-H), 7.42-7.47 (m, 3H, 3xAr-H), 7.49 (d, 1H, J=4.2 Hz, 4 '-H), 9.75 (s, 1H, CHO). ${ }^{13} \mathrm{C} \mathrm{NMR}\left(\mathrm{CDCl}_{3}\right) \delta 109.99,113.05,124.42,126.88,126.94$, 128.42, 129.40 (two overlapped signals), 136.88, 139.38, 140.73, 145.25, 182.49. Anal. 
Calcd for $\mathrm{C}_{15} \mathrm{H}_{11} \mathrm{NOS}$ : C, 71.13; H, 4.35; N, 5.53; S, 12.67. Found: C, 70.98; H, 4.54; N, 5.58; S, 12.69 .

Metalation of thienylpyrrole 2c followed by a reaction with DMF gave a mixture of 1(4"'-methoxyphenyl)-2-(5'-formyl-2'-thienyl)pyrrole 5c and 1-(3"'-formyl-4"methoxyphenyl)-2-(5'-formyl-2'-thienyl)pyrrole 6c. The first compound eluted was 1(4'-methoxyphenyl)-2-(5'-formyl-2'-thienyl)pyrrole 5c as a green solid (63\%). Mp: 96.6-97.4 ${ }^{\circ} \mathrm{C}$. UV (EtOH): $\lambda \max \mathrm{nm}\left(\varepsilon / \mathrm{M}^{-1} \mathrm{~cm}^{-1}\right) 379.0$ (18613), 270.0 inf. (6000), 230.5 (16603), 203.5 (24294). IR (liquid film): v 1659 (CHO), 1609, 1539, 1515, 1462, 1444, 1412, 1299, 1250, 1231, 1182, 1169, 1158, 1106, 1061, 917, 836, 797, 755, 724, 666, $619 \mathrm{~cm}^{-1} .{ }^{1} \mathrm{H} \mathrm{NMR}\left(\mathrm{CDCl}_{3}\right) \delta 3.87\left(\mathrm{~s}, 3 \mathrm{H}, \mathrm{OCH}_{3}\right), \delta 6.32-6.36(\mathrm{~m}, 1 \mathrm{H}, 4-\mathrm{H}), 6.67$ (d, $\left.1 \mathrm{H}, J=4.2 \mathrm{~Hz}, 3^{\prime}-\mathrm{H}\right), 6.70$ (dd, $1 \mathrm{H}, J=3.6$ and $\left.1.8 \mathrm{~Hz}, 3-\mathrm{H}\right), 6.88-6.91(\mathrm{~m}, 1 \mathrm{H}, 5-\mathrm{H})$, 6.95 (d, 2H, J=9.0 Hz, 2xAr-H), 7.22 (d, 2H, J=9.0 Hz, 2xAr-H), 7.49 (d, 1H, J=4.2 Hz, 4'-H), 9.74 (s, 1H, CHO). ${ }^{13} \mathrm{C}$ NMR $\left(\mathrm{CDCl}_{3}\right) \delta 55.45,109.63,112.33,114.41,124.02$, $127.13,127.19,128.21,132.04,136.98,140.43,145.32,159.52,182.46$. MS (EI) $\mathrm{m} / \mathrm{z}$ (\%): $283\left(\mathrm{M}^{+}, 100\right), 268$ (54), 240 (6), 121 (8), 103 (5). HRMS: (EI) m/z (\%) for $\mathrm{C}_{16} \mathrm{H}_{13} \mathrm{NO}_{2} \mathrm{~S}$; calcd 283.0667; found 283.0665. Anal. Calcd for $\mathrm{C}_{16} \mathrm{H}_{13} \mathrm{NO}_{2} \mathrm{~S}$ : C, 67.83; H, 4.59; N, 4.94; S, 11.33. Found: C, 67.78; H, 4.82; N, 5.02; S, 11.25. The second compound eluted was 1-(3"'-formyl-4"'-methoxyphenyl)-2-(5'-formyl-2'thienyl)pyrrole $6 \mathrm{c}$ as a orange oil $(5 \%)$. UV (EtOH): $\lambda \max n \mathrm{~nm}\left(\varepsilon / \mathrm{M}^{-1} \mathrm{~cm}^{-1}\right) 374.0$ (10605), 270.0 inf. (5000). IR (liquid film): $v 1684(\mathrm{C}=\mathrm{O}), 1659(\mathrm{C}=\mathrm{O}), 1611,1499$, 1462, 1394, 1273, 1234, 1122, 1019, 869, 817, 755, 726, $666 \mathrm{~cm}^{-1}$. ${ }^{1} \mathrm{H}$ NMR (Acetone$\left.\mathrm{d}_{6}\right) \delta 4.11\left(\mathrm{~s}, 3 \mathrm{H}, \mathrm{OCH}_{3}\right), 6.37-6.40(\mathrm{~m}, 1 \mathrm{H}, 4-\mathrm{H}), 6.80(\mathrm{dd}, 1 \mathrm{H}, J=3.8$ and $1.2 \mathrm{~Hz}, 3-\mathrm{H})$, $6.91(\mathrm{~d}, 1 \mathrm{H}, J=3.9 \mathrm{~Hz}, 3$ '-H), 7.09-7.11 (m, 1H, 5-H), 7.41 (d, 2H, J=8.7 Hz, 5' '-H), 7,65 (dd, 1H, J=8.7 and $2.4 \mathrm{~Hz}, 6$ ' '-H), 7.69 (d, 1H, J=2.4 Hz, 2' -H), 7.75 (d, 1H, $J=3.9 \mathrm{~Hz}, 4$ '-H), 9.81 (s, 1H, CHO), 10.48 (s, 1H, CHO). ${ }^{13} \mathrm{C} \mathrm{NMR}\left(\mathrm{CDCl}_{3}\right) \delta 56.06$, $110.18,112.56,112.92,124.49,125.07,126.56,127.02,127.07,132.36,134.26$, 137.01, 140.92, 144.81, 161.43, 182.53, 188.68. MS (EI) m/z (\%): $311\left(\mathrm{M}^{+}, 100\right), 285$ (5), 268 (30), 235 (6). HRMS: (EI) $\mathrm{m} / \mathrm{z}(\%)$ for $\mathrm{C}_{17} \mathrm{H}_{13} \mathrm{NO}_{3} \mathrm{~S}$; calcd 311.0616; found 311.0625 .

Metalation of thienylpyrrole 2d followed by a reaction with DMF gave a mixture of thienylpyrrole 2d, 1-(2",4"-dimethoxyphenyl)-2-(5'-formyl-2'-thienyl)pyrrole 5d and 
1-(3"-formyl-2"',4"-dimethoxyphenyl)-2-(2'-thienyl)pyrrole 7d. The first compound eluted was pyrrole $\mathbf{2 d}$ as a green solid (40\%). The second component eluted was 1-(3"formyl-2",4"-dimethoxyphenyl)-2-(2'-thienyl)pyrrole 7d as a dark green oil (8\%). IR (liquid film): v 3108, $1693(\mathrm{C}=\mathrm{O}), 1659,1581,1492,1442,1397,1334,1288,1232$, 1186, 1164, 1121, 1096, 1013, 948, 842, 814, $716 \mathrm{~cm}^{-1} .{ }^{1} \mathrm{H}$ NMR $\left(\mathrm{CDCl}_{3}\right) \delta 3.48(\mathrm{~s}$, $\left.3 \mathrm{H}, \mathrm{OCH}_{3}\right), 3.96\left(\mathrm{~s}, 3 \mathrm{H}, \mathrm{OCH}_{3}\right), 6.33-6.38(\mathrm{~m}, 1 \mathrm{H}, 4-\mathrm{H}), 6.54(\mathrm{dd}, 1 \mathrm{H}, J=4.2$ and 1.8 $\mathrm{Hz}, 3-\mathrm{H}), 6.70$ (dd, $1 \mathrm{H}, J=3.6$ and $1.2 \mathrm{~Hz}, 3$ '-H), 6.75 (d, 1H, J=9.0 Hz, 6' '-H or 5' '-H), 6.80-6.83 (m, 1H, 5-H), 6.86-6.90 (m, 1H, 4'-H), $7.08(\mathrm{dd}, 1 \mathrm{H}, J=5.1$ and $1.2 \mathrm{~Hz}, 5$ '$\mathrm{H}), 7.42(\mathrm{~d}, 1 \mathrm{H}, \mathrm{J}=9.0 \mathrm{~Hz}, 6$ ' $-\mathrm{H}$ or 5 ' $-\mathrm{H}), 10.45(\mathrm{~s}, 1 \mathrm{H}, \mathrm{CHO}) .{ }^{13} \mathrm{C}$ NMR $\left(\mathrm{CDCl}_{3}\right)$ $\delta$ 56.28, 61.44, 106.44, 109.59, 109.72, 119.05, 123.71, 123.88, 125.04, 125.72, 127.07, 128.54, 134.70, 135.92, 158.82, 161.18, 189.14. MS (EI) m/z (\%): $313\left(\mathrm{M}^{+}, 100\right), 298$ (17), 284 (13), 270 (9), 255 (5), 121 (9). HRMS: (EI) m/z (\%) for $\mathrm{C}_{17} \mathrm{H}_{15} \mathrm{NO}_{3} \mathrm{~S}$; calcd 313.0772; found 313.0785. The third compound eluted was 1-(2", $44^{\prime \prime}$ dimethoxyphenyl)-2-(5'-formyl-2'-thienyl)pyrrole 5d as a dark green oil (48 \%). UV (EtOH): $\lambda_{\max } \mathrm{nm}\left(\varepsilon / \mathrm{M}^{-1} \mathrm{~cm}^{-1}\right) 384.5$ (18158), 277.5 (6264), 233.0 (1312), 207.0 (30609). IR (liquid film): v 2962, 2838, 1652 (CHO), 1613, 1589, 1541, 1516, 1462, 1443, 1416, 1383, 1306, 1286, 1260, 1232, 1210, 1161, 1135, 1092, 1062, 1046, 1030, 928, 911, 803, $728 \mathrm{~cm}^{-1} .{ }^{1} \mathrm{H} \mathrm{NMR}\left(\mathrm{CDCl}_{3}\right) \delta 3.66\left(\mathrm{~s}, 3 \mathrm{H}, \mathrm{OCH}_{3}\right), 3.89\left(\mathrm{~s}, 3 \mathrm{H}, \mathrm{OCH}_{3}\right)$, 6.34-6.38 (m, 1H, 4-H), 6.52-6.58 (m, 2H, 3'"-H and 5' -H), 6.74 (dd, 1H, J=3.9 and $1.8 \mathrm{~Hz}, 3-\mathrm{H}), 6.80-6.84$ (m, 2H, 3'-H and 5-H), 7.17 (d, 1H, J=9.3 Hz, 6' -H), 7.51 (d, $1 \mathrm{H}, J=4.2 \mathrm{~Hz}, 4$ '-H), 9.73 (s, $1 \mathrm{H}, \mathrm{CHO}) .{ }^{13} \mathrm{C} \mathrm{NMR}\left(\mathrm{CDCl}_{3}\right) \delta 55.54,55.69,99.72$, $104.41,109.56,111.33,121.03,123.11,127.34,128.00,129.78,137.08,140.00$, 145.78, 156.40, 161.39, 182.51. MS (EI) m/z (\%): $313\left(\mathrm{M}^{+}, 100\right), 270$ (8), 255 (8). HRMS: (EI) $\mathrm{m} / \mathrm{z}(\%)$ for $\mathrm{C}_{17} \mathrm{H}_{15} \mathrm{NO}_{3} \mathrm{~S}$; calcd 313.0773; found 313.0770. Anal. Calcd for $\mathrm{C}_{17} \mathrm{H}_{15} \mathrm{NO}_{3} \mathrm{~S}: \mathrm{C}, 65.16 ; \mathrm{H}, 4.79 ; \mathrm{N}, 4.47 ; \mathrm{S}, 10.24$. Found: $\mathrm{C}, 65.14 ; \mathrm{H}, 5.07 ; \mathrm{N}$, 4.58; S, 10.04 .

Metalation of thienylpyrrole 2d during $2 \mathrm{~h}$ followed by $2 \mathrm{~h}$ of reflux with DMF gave a mixture of 4 compounds: thienylpyrrole 2d (18\%), 1-(2",4"-dimethoxyphenyl)-2-(5'formyl-2'-thienyl)pyrrole 5d (34\%), 1-(3"'-formyl-2",4"'-dimethoxyphenyl)-2-(2'thienyl)pyrrole 7d (14\%) and 1-(3"'-formyl-2",4"'-dimethoxyphenyl)-2-(5'-formyl-2'thienyl)pyrrole $\mathbf{6 d}$ as a dark orange oil (18\%). UV (EtOH): $\lambda_{\max } \mathrm{nm}\left(\varepsilon / \mathrm{M}^{-1} \mathrm{~cm}^{-1}\right)$ 377.0 (16040), 260.5 (14720). IR (liquid film): $v 1690(\mathrm{C}=\mathrm{O}), 1657(\mathrm{C}=\mathrm{O}), 1492,1461$, 
1288, 1231, 1094, 1019, 812, $608 \mathrm{~cm}^{-1} .{ }^{1} \mathrm{H}$ NMR $\left(\mathrm{CDCl}_{3}\right) \delta 3.48\left(\mathrm{~s}, 3 \mathrm{H}, \mathrm{OCH}_{3}\right), 4.00$ (s, 3H, $\left.\mathrm{OCH}_{3}\right), 6.39-6.42(\mathrm{~m}, 1 \mathrm{H}, 4-\mathrm{H}), 6.77(\mathrm{dd}, 1 \mathrm{H}, \mathrm{J}=3.6$ and $1.5 \mathrm{~Hz}, 3-\mathrm{H}), 6.82$ (d, $1 \mathrm{H}, \mathrm{J}=9.0 \mathrm{~Hz}, 5$ ' '-H), 6.85-6.90 (m, 2H, 3'-H and 5-H), 7.46 (d, 1H, J=9.0 Hz, 6' '-H), 7.54 (d, 1H, J=4.2 Hz, 4'-H), 9.75 (s, 1H, CHO), 10.45 (s, 1H, CHO). ${ }^{13} \mathrm{C}$ NMR $\left(\mathrm{CDCl}_{3}\right) \delta$ 56.35, 61.79, 106.96, 110.46, 112.23, 119.37, 123.62, 125.26, 127.47, $127.87,135.43,137.30,140.62,144.74,158.44,161.99,182.49,188.79$. MS (EI) $\mathrm{m} / \mathrm{z}$ (\%): $341\left(\mathrm{M}^{+}, 100\right), 326$ (7), 312 (13), 298 (7), 83 (9). HRMS: (EI) m/z (\%) for $\mathrm{C}_{18} \mathrm{H}_{15} \mathrm{NO}_{4} \mathrm{~S}$; calcd 341.0722; found 341.0710.

1-(3",4",5"'-Trimethoxyphenyl)-2-(5'-formyl-2'-thienyl)pyrrole 5e. Metalation of thienylpyrrole $2 \mathbf{e}$ followed by a reaction with DMF gave a mixture of thienylpyrrole $\mathbf{2 e}$ and 1-(3",4",5"-Trimethoxyphenyl)-2-(5'-formyl-2'-thienyl)pyrrole 5e. The first component eluted thienylpyrrole $2 \mathbf{e}$ as a pale green solid (40\%). The second component eluted was 1-(3",4",5"-Trimethoxyphenyl)-2-(5'-formyl-2'-thienyl)pyrrole $5 \mathbf{e}$ as an yellow oil (12\%). Mp: 113.5-114.7 ${ }^{\circ} \mathrm{C}$. UV (EtOH): $\lambda_{\max } \mathrm{nm}\left(\varepsilon / \mathrm{M}^{-1} \mathrm{~cm}^{-1}\right) 377.0$ (11860), 265.0 inf. (6820). IR (liquid film): v 2935, 1659 (CHO), 1596, 1507, 1463, $1417,1262,1230,1127,1066,1033,1004,840,808,727,668 \mathrm{~cm}^{-1} .{ }^{1} \mathrm{H} \mathrm{NMR}\left(\mathrm{CDCl}_{3}\right)$ $\delta 3.79$ (s, 6H, 2xOCH$), 3.92\left(\mathrm{~s}, 3 \mathrm{H}, \mathrm{OCH}_{3}\right)$, 6.34-6.37 (m, 1H, 4-H), 6.52 (br s, 2H, 2' 'and 6"'-H), $6.66\left(\mathrm{~d}, 1 \mathrm{H}, J=4.2 \mathrm{~Hz}, 3^{\prime}-\mathrm{H}\right), 6.71(\mathrm{dd}, 1 \mathrm{H}, J=3.8$ and $1.5 \mathrm{~Hz}, 3-\mathrm{H}), 6.89$ $6.93(\mathrm{~m}, 1 \mathrm{H}, 5-\mathrm{H}), 7.52$ (d, 1H, J=3.9 Hz, 4'-H), 9.77 (s, 1H, CHO). ${ }^{13} \mathrm{C}$ NMR $\left(\mathrm{CDCl}_{3}\right)$ $\delta 55.45,109.63,112.33,114.41,124.02,127.13,127.19,128.21,132.04,136.98$, 140.43, 145.32, 159.52, 182.46. MS (EI) m/z (\%): $343\left(\mathrm{M}^{+}, 100\right), 328$ (50), 300 (6). HRMS: (EI) $\mathrm{m} / \mathrm{z}(\%)$ for $\mathrm{C}_{18} \mathrm{H}_{17} \mathrm{NO}_{4} \mathrm{~S}$; calcd 343.0878; found 343.0896.

1-(4',-Fluorophenyl)-2-(5'-formyl-2'-thienyl)pyrrole 5f. Metalation of thienylpyrrole $2 \mathbf{f}$ followed by a reaction with DMF gave a mixture of thienylpyrrole $2 \mathrm{f}$ and 1-(4', Fluorophenyl)-2-(5'-formyl-2'-thienyl)pyrrole 5f. The first component eluted thienylpyrrole $2 \mathbf{f}$ as a pale yellow solid (15\%). The second component eluted was the 1(4',-Fluorophenyl)-2-(5'-formyl-2'-thienyl)pyrrole 5 f as a brown solid (25\%). Mp: 112$114{ }^{\circ} \mathrm{C}$. UV (EtOH): $\lambda_{\max } \mathrm{nm}\left(\varepsilon / \mathrm{M}^{-1} \mathrm{~cm}^{-1}\right) 373.5$ (15191), 257.6 (6386), 226.0 (8830), 204.0 (17041). IR (liquid film): $v 1659$ (CHO), 1511, 1462, 1439, 1412, 1349, 1221, $1189,1154,1094,1061,1039,916,842 \mathrm{~cm}^{-1} .{ }^{1} \mathrm{H}$ NMR $\left(\mathrm{CDCl}_{3}\right) \delta 6.30-6.40$ (m, 1H, 4H), 6.63 (d, 1H, J=4.2 Hz, 3'-H), 6.65-6.75 (m, 1H, 3-H), 6.85-6.90 (m, 1H, 5-H), 7.13 
( $\mathrm{t}_{\mathrm{ap}}, 2 \mathrm{H}, J=8.4 \mathrm{~Hz}, 3$ ', and 5' '-H), 7.25-7.35 (m, 2H, 2', and 6' '-H), 7.49 (d, 1H, J=4.2 Hz, 4'-H), 9.75 (s, 1H, CHO). MS (EI) m/z (\%): $271\left(\mathrm{M}^{+}, 100\right), 243$ (3), 242 (8), 209 (5), 198 (6), 185 (5), 150 (9), 133 (6), 121 (6), 95 (5), 75 (4). HRMS: (EI) m/z (\%) for $\mathrm{C}_{15} \mathrm{H}_{10} \mathrm{FNOS}$; calcd 271.0467; found 271.0465.

\section{Acknowledgements}

Thanks are due to Foundation for Science and Technology (Portugal) for financial support through IBQF (UM) and through POCTI, FEDER (ref. POCTI/QUI/37816/2001).

\section{References and notes}

1. March, J., Advanced Organic Chemistry; $4^{\text {th }}$ edn; Wiley-Interscience: New York, 1992, 542 and references cited therein.

2. Schlosser, M. Angew. Chem. Int. Ed. 2005, 44, 376 and references cited therein.

3. Chinchilla, R.; Nájera, C.; Yus, M. Chem. Rev. 2004, 104, 2667.

4. Jackson, A. H., Pyrroles In The Chemistry of Heterocyclic Compounds; Vol. 48, Part 1; Jones, R. A., Ed.; Wiley: New York, 1990, 295 and references cited therein.

5. Bird, C. W., Ed.; Comprehensive Heterocyclic Chemistry II; Vol. 2, Pergamon: Oxford, 1996, 1.

6. Castiñeiras, A.; Carballo, R.; Pérez, T. Polyhedron 2001, 20, 441.

7. Alonso, R.; Bermejo, E.; Castiñeiras, A.; Carballo, R.; Pérez, T. J. Mol. Struct. 2002, 606, 155.

8. Rodríguez-Argüelles, M.; López-Silva, E. C.; Sanmartìn, J.; Pelagatti, P.; Zani, F., J. Inorg. Biochem. 2005, 99(11), 2231.

9. Won, D.-H.; Lee, C.-H. Tetrahedron Lett. 2003, 44(35), 6695.

10. Beecher, J. E.; Tirrell, D. A. Tetrahedron Lett. 1998, 39(23), 3927.

11. Haldar, P.; Guin, J.; Ray, J. K. Tetrahedron Lett. 2005, 46(7), 1071.

12. Pichon-Santander, C.; Scott, A. I. Tetrahedron Lett. 2000, 41(16), 2825.

13. Rodríguez, J. G.; Lafuente, A.; Rubio, L. Tetrahedron Lett. 2004, 45(29), 5685. 
14. Toba, M.; Takeoka, Y.; Rikukawa, M.; Sanui, K. Synyhetic Metals. 2005, 152(1-3), 197.

15. Fan, Q.-L.; Zhang, G.-W.; Lu, X.-M.; Chen, Y.; Huang, Y.-Q.; Zhou, Y.; Chan, H. S. O.; Lai, Y.-H.; Xu, G.-Q.; Huang, W. Polymer 2005, 46(24), 11165.

16. Purkarthofer, T.; Gruber, K.; Fechter, M. H.; Griengl, H. Tetrahedron 2005, 61(32), 7661.

17. Takekuma, S.-I; Takahashi, K.; Sakaguchi, A.; Shibata, I.; Sasaki, M.; Minematsu, T.; Takekuma, H. Tetrahedron 2005, 61(32), 10349.

18. Hareau, G. P.-J.; Neya, S.; Funasaki, N.; Taniguchi, I. Tetrahedron Lett. 2002, 43(17), 3109.

19. Simionescu, C. I.; Grigoras, M.; Cianca, I.; Olaru, N. Eur. Polym. J. 1998, 34(7), 891.

20. Mignani G.; Leising F.; Meyrueix R.; Samson M., Tetrahedron Lett. 1990, 31 (33), 4743.

21. Effenberger, F.; Wurthner, F.; Steybe F. J. Org. Chem. 1995, 60, 2082.

22. Eckert, K.; Schroder, A.; Hartmann, H. Eur. J. Org. Chem. 2000, 1327 and references cited therein.

23. Turbiez, M., P.; Frère, P.; Roncali, J. Tetrahedron 2005, 61, 3045.

24. Mason, C. R.; Skabara, P. J.; Cupertino, D.; Schofield, J.; Meghdadi, F.; Ebner, B.; Sariciftci, N. S. J. Mater. Chem. 2005, 15, 1446.

25. Raposo, M. M. M.; Kirsch, G. Tetrahedron 2003, 59(26), 4891.

26. Raposo, M. M. M.; Fonseca, A. M. C.; Kirsch, G. Tetrahedron 2004, 60(18), 4071.

27. Batista, R. M. F.; Costa, S. P. G.; Raposo, M. M. M. Tetrahedron Lett. 2004, 45(13), 2825.

28. Raposo, M. M. M.; Sousa, A. M. R. C.; Fonseca, A. M. C.; Kirsch, G. Tetrahedron, 2005, 61(34), 8249-8256.

29. Raposo, M. M. M.; Sousa, A. M. R. C.; Kirsch, G.; Ferreira, F.; Belsey, M.; Matos Gomes; Fonseca, A. M. C. Tetrahedron, 2005, 61(50), 11991-11998. 
30. Raposo, M. M. M.; Fonseca, A. M. C.; Sousa, A. M. R. C.; Kirsch, G. Mater. Sci. Forum 2006, 514-516, 98-102.

31. Raposo, M. M. M.; Fonseca, A. M. C.; Sousa, A. M. R. C.; Kirsch, G. Mater. Sci. Forum 2006, 514-516, 103-107.

32. Raposo, M. M. M.; Sampaio, A. M. B. A.; Kirsch, G. J. Heterocyclic Chem. 2005, 42(7), 1245.

33. Costa, F., Silva; C. J. R.; Raposo, M. M. M.; Fonseca, A. M.; Neves, I. C.; Carvalho, A. P.; Pires, J. Microporous Mesoporous Mater. 2004, 72, 111.

34. Fonseca, A. M. C.; Raposo, M. M. M.; Sousa, A. M. R. C.; Kirsch, G.; Beley, M. Eur. J. Inorg. Chem. 2005, 21, 4361.

35. Raposo, M. M. M.; Sampaio, A. M. B. A.; Kirsch, G. Synthesis 2005, 2, 199.

36. Raposo, M. M. M.; Kirsch G. Heterocycles 2001, 55(8), 1487.

37. Belen'kii, L. I. Kim. Geterotsikl. Soed. 1980, 12, 1587.

38. Belen'kii, L. I. Heterocycles 1994, 37(3), 2029.

39. Boukou-Poba, J.-P.; Farnier, M.; Guilard, R. Tetrahedron Lett. 1979, $20(19), 1717$.

40. Boukou-Poba, J.-P.; Farnier, M.; Guilard, R. Can. J. Chem. 1981, 59, 2962.

41. Trofimov, B. A.; Korostova, S. E.; Mikhaleva, A. I.; Nesterenko, R.N.; Sigalov, M. V.; Voronov, V. K.; Polovnikova, R. I. Zh. Org. Kim. 1982, 18, 894.

42. Korostova, S. E.; Nesterenko, R. N.; Mikhaleva, A. I.; Shevchenko, S. G.; Kalabin, G. A.; Polovnikova, R. I. Kim Geterotsikl. Soedin. 1990, 273.

43. Korostova, S. E.; Nesterenko, R. N.; Mikhaleva, A. I.; Shevchenko, S. G.; Kalabin, G. A.; Polovnikova, R. I. Kim. Geterotsikl. Soed. 1991, 337.

44. Korostova, S. E.; Mikhaleva, A. I.; Trofimov, B. A. Russ. Chem. Rev. (Engl. Transl.) 1999, 68(6), 459.

45. Trofimov, B. A.; Sobenina, L. N.; Demenev, A. P.; Mikhaleva, A. I.; Ushakov, I. A.; Tarasova, O. A.; Smirnov, V. I.; Petrushenko, K. B.; Vokin, A. I.; Murzina, N. M.; Myachina, G. F. Arkivok 2001, ix, 37.

46. Niziursky-Mann; R. E.; Cava, M. P. Heterocycles 1992, 34(10), 2003.

47. Majchrzak, M. W. and Simchen, G. Tetrahedron 1986, 42, 1299. 
48. Muchowski, J. M.; Naef, R. Helv. Chim. Acta 1984, 67, 1168 and references cited therein.

49. Kozikowski, A. P.; Cheng, X.-M. J. Org. Chem. 1984, 49, 3239.

50. Stefan, K.-P.; Schuhmann, W.; Parlar, H.; Korte, Friedhelm Chem. Ber. 1989, 122, 169.

51. Lomas, J. S.; Vaissermann, J. J. Chem. Soc Perkin Trans. 2 1998, 1777.

52. Robertson, J.; Kuhnert, N.; Zhao, Y. Heterocycles 2000, 53(11), 2415.

53. Selvi, S.; Pu, S.-C.; Cheng, Y.-M.; Fang, J.-M.; Chou, P.-T. J. Org. Chem. 2004, $69,6674$.

54. Martineau, D.; Gros, P.; Fort, Y. J. Org. Chem. 2004, 69, 7914.

55. Faigl, F.; Fogassy, K.; Thurner, A.; Toke, László, T. Tetrahedron 1997, 53(13), 4883.

56. Faigl, F.; Fogassy, K.; Szántó, Z.; Lopata, A.; Toke, L. Tetrahedron 1998, 54(17), 4367.

57. Faigl, F.; Fogassy, K.; Szucs, E.; Kovács, K.; Keserú, Gy.-M.; Harmat, V.; Böcskei, Zs.; Toke, L. Tetrahedron, 1999 55(25), 7881.

58. Fogassy, K.; Kovács, K.; Keserú, G. M.; Toke, L.; Faigl, F.; J. Chem. Soc. Perkin Trans. 1 2001, 1039.

59. Faigl, F.; Thurner, A.; Vass, B.; Toke, L. J. Chem. Research (S) 2003, 132.

60. Snieckus, V. Chem. Rev. 1990, 90 (6), 879 and references cited therein.

61. Casado, J.; Pappenfus, T. M.; Miller, L. L.; Mann, K. R.; Orti, E.; Viruela, P. M.; Pou-Amerigo, R.; Hernandez, V.; Navarrete, J. T. L. J. Am. Chem. Soc. 2003, 125 , 2524 .

\section{Captions}

Scheme 1. Synthesis of formyl-thienylpyrroles 3-4 from thienylpyrroles 2 by Vilsmeier-Haack reaction with DMF. 
Scheme 2. Synthesis of formyl-thienylpyrroles 5-7 from thienylpyrroles 2 by $\mathrm{m}$ followed by reaction with DMF.

Table 1. Yields, ${ }^{1} \mathrm{H}$ NMR, IR and UV-vis data of formyl-thienylpyrroles 3-4.

a For the $\mathrm{CHO}$ proton of formyl-thienylpyrroles 3-4 (300 $\left.\mathrm{MHz}, \mathrm{CDCl}_{3}\right)$

b For the CHO proton of formyl-thienylpyrroles 3-4 (300 MHz, Acetone- $\left.\mathrm{d}_{6}\right)$.

c All the UV/vis spectra were run in ethanol.

Table 2. Yields, ${ }^{1} \mathrm{H}$ NMR, IR and UV-vis data of formyl-thienylpyrroles 5-7.

a Yields for compounds $\mathbf{5 d - 7 d}$ obtained for $2 \mathrm{~h}$ of lithiation followed by $2 \mathrm{~h}$ of reaction with DMF.

b For the $\mathrm{CHO}$ proton of formyl-thienylpyrroles 5-7 (300 MHz, $\left.\mathrm{CDCl}_{3}\right)$.

c For the CHO proton of formyl-thienylpyrroles 5-7 (300 MHz, acetone- $\left.\mathrm{d}_{6}\right)$.

d All the UV/vis spectra were run in ethanol. 
Tables

Table 1

\begin{tabular}{|c|c|c|c|c|c|c|}
\hline Entry & Pyrrole & $\begin{array}{l}\text { Formyl- } \\
\text { pyrrole }\end{array}$ & $\begin{array}{l}\text { Yield } \\
(\%)\end{array}$ & $\begin{array}{c}\delta_{\mathrm{H}} \\
(\mathbf{p p m})^{\mathrm{a}}\end{array}$ & $\begin{array}{c}\text { IR }{ }^{\mathrm{CHO}} \\
{\left[\mathrm{cm}^{-1}\right]}\end{array}$ & $\begin{array}{c}\mathrm{UV} / \mathrm{vis} \\
\lambda_{\max }[\mathrm{nm}]^{\mathrm{c}}(\varepsilon)\end{array}$ \\
\hline 1 & 2a & 3a & 63 & 9.54 & 1658 & $321.5(24,650)$ \\
\hline 2 & $2 a$ & $4 a$ & 5 & 9.54 & 1662 & $293.5(5440)$ \\
\hline 3 & $2 b$ & $3 b$ & 19 & 9.39 & 1660 & $340.5(20,100)$ \\
\hline 4 & $2 \mathbf{b}$ & $4 b$ & 22 & $9.82^{\mathrm{b}}$ & 1661 & $325.0(7440)$ \\
\hline 5 & 2c & $3 c$ & 12 & 9.38 & 1655 & $343.0(21,559)$ \\
\hline 6 & 2c & 4c & 10 & $9.81^{b}$ & 1661 & ---------- \\
\hline
\end{tabular}


Table 2

\begin{tabular}{|c|c|c|c|c|c|c|c|}
\hline Entry & Pyrrole & $\begin{array}{c}\text { UV/vis. } \\
\lambda_{\text {max }}[\mathrm{nm}]^{\mathrm{d}}(\varepsilon)\end{array}$ & $\begin{array}{l}\text { Formyl- } \\
\text { pyrrole }\end{array}$ & $\begin{array}{l}\text { Yield } \\
(\%)\end{array}$ & $\begin{array}{c}\delta_{H} \\
(p p m)^{b}\end{array}$ & $\begin{array}{c}\text { IR }{ }_{\mathrm{CHO}} \\
{\left[\mathrm{cm}^{-1}\right]}\end{array}$ & $\begin{array}{c}\text { UV/vis. } \\
\lambda_{\text {max }}[\mathrm{nm}]^{\mathrm{d}}(\varepsilon)\end{array}$ \\
\hline 1 & $2 \mathbf{a}$ & $291.0(1800)$ & $5 a$ & 68 & 9.87 & 1659 & $374.0(9474)$ \\
\hline 2 & $2 \mathbf{b}$ & 294.5 (9208) & $5 b$ & 78 & 9.75 & 1659 & $374.0(19,180)$ \\
\hline 3 & 2c & $290.0(11,410)$ & $5 c$ & 63 & 9.74 & 1659 & $379.0(18,613)$ \\
\hline 4 & 2c & ----- & $6 c$ & 5 & $9.81^{\mathrm{c}}, 10.48^{\mathrm{c}}$ & 1659,1684 & $374.0(10,605)$ \\
\hline 5 & 2d & $286.5(10,093)$ & $5 d$ & $48,34^{\mathrm{a}}$ & 9.73 & 1652 & $384.5(18,158)$ \\
\hline 6 & 2d & ----- & 6d & $18^{a}$ & $9.75,10.45$ & 1657,1690 & $377.0(16,040)$ \\
\hline 7 & 2d & ----- & $7 d$ & $8,14^{\mathrm{a}}$ & 10.45 & 1693 & ----- \\
\hline 8 & $2 \mathbf{e}$ & $281.5(8477)$ & $5 e$ & 12 & 9.77 & 1659 & $377.0(11,860)$ \\
\hline 9 & $2 f$ & 289.5 (7939) & $5 f$ & 25 & 9.75 & 1659 & $373.5(15,191)$ \\
\hline
\end{tabular}


Scheme 1

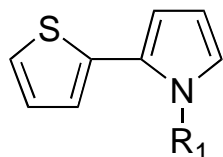

a $\quad \mathrm{R}_{1}=$ n-Propyl

b $\mathrm{R}_{1}=$ Phenyl

$\mathrm{R}_{1} \quad$ c $\quad \mathrm{R}_{1}=4-$ MeOPhenyl

2 a-c $\mathrm{POCl}_{3} / \mathrm{DMF} / 60^{\circ} \mathrm{C}$<smiles>[R1]n1c(C=O)ccc1-c1cccs1</smiles>

3 a-c<smiles>[R1]n1ccc(C=O)c1-c1cccs1</smiles>

4 a-c

Scheme 2

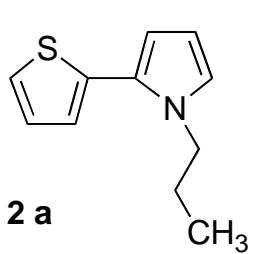

i) $n$-BuLi / $0{ }^{\circ} \mathrm{C} /$ dry ether

ii) DMF / reflux
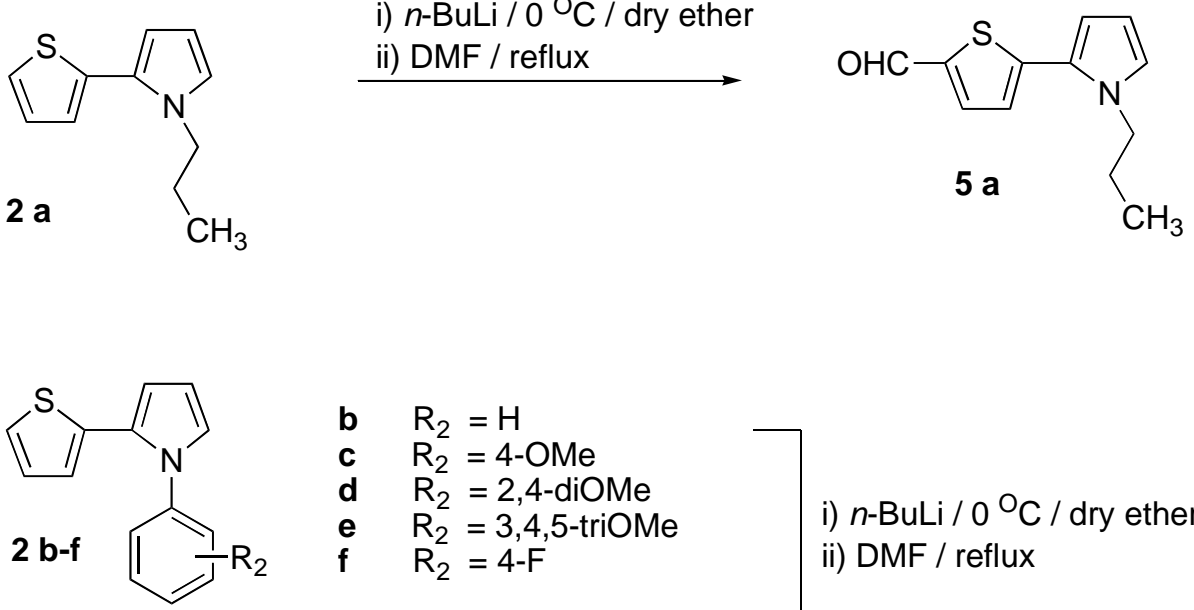

b $\quad \mathrm{R}_{2}=\mathrm{H}$

c $\quad \mathrm{R}_{2}=4-\mathrm{OMe}$

d $\mathrm{R}_{2}=2,4$-diOMe

e $\quad R_{2}=3,4,5$-triOMe

i) $n$-BuLi / $0{ }^{\circ} \mathrm{C} /$ dry ether

ii) DMF / reflux<smiles>O=Cc1ccc(-c2cccn2-c2ccccc2)s1</smiles><smiles>O=Cc1c[R1]cc(-n2cccc2-c2ccc(C=O)s2)c1</smiles><smiles>COc1ccc(-n2cccc2-c2cccs2)c(OC)c1C=O</smiles> 


\section{Graphical Abstract}

\section{Synthesis of formyl-thienylpyrroles: versatile building blocks for NLO materials}

M. Manuela M. Raposoa*, Ana M. R. C. Sousa ${ }^{a}$, A. Maurício C. Fonseca ${ }^{a}$ and G. Kirsch ${ }^{b}$

${ }^{a}$ Centro de Química, Universidade do Minho, Campus de Gualtar 4710-057 Braga, Portugal

${ }^{b}$ Laboratoire d'Ingénierie Moléculaire et Biochimie Pharmacologique, UFR SciFA, Université de Metz, 1, Boulevard Arago,

Metz Technopôle, 57078 Metz Cedex 3, France
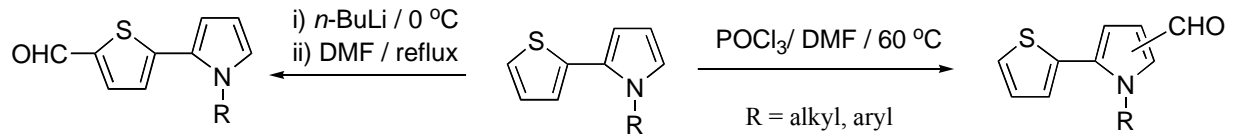